\title{
Survey on Rural Residents' Religion-A Case of Christian Faith of Z Village's Residents in South Henan
}

\author{
Jun-hua WANG ${ }^{1}$, Ye-xi ZHONG ${ }^{1,{ }^{*}}$ and Shu-ming BAO ${ }^{2}$ \\ ${ }^{1}$ School of Geography and Environment, Jiangxi Normal University, \\ Nanchang 330022, China \\ ${ }^{2}$ China Data Center, University of Michigan, Ann Arbor 48106, USA \\ *Ye-xi ZHONG, Tel: 13677919288, E-mail:407171815@qq.com
} Keywords: Countryside, Christianity, Positive function, New countryside
construction.

\begin{abstract}
Since the reform and opening up, especially in recent years, Christianity has been developing rapidly in the countryside, which has a huge impact on rural social governance. Combined with fieldwork and combing literature, a thorough investigation into $\mathrm{Z}$ village had been taken to acquire the condition of local residents' Christian faith, further the reason of Christian expansion and Christian social function have been dissected. The results show that low entry threshold, localization reform, preaching innovation and concerning Christians, etc. are important factors of Christian expansion rapidly in rural areas. What's more, Christianity starts to become a positive force to maintain social order, improve social interaction and raise the public morality.
\end{abstract}

\section{Introduction}

Since the reform and opening up in 1978, social economy in rural areas has been improved; meanwhile, issues about religious faith are increasingly apparent, which appeal widespread attention of scholars at home and abroad. Zhang Yan analyzed religious issues in rural ethic areas through investigation and provided some countermeasures [1].Wang Jian carried out a survey on religious faith of rural residents to discover its new conditions and new characteristics [2]. Then OuYang Sutong accounted for the significance of religion to rural society from the perspective of social science and intellectual history, and his representative work was "Chinese rural religion under the background of transformation"[3]. In recent decades, there was a rapid development of rural Christianity in Henan Province, so the increasing scholars began to keep a watchful eye on it. For instance, Ma Xiaojun explored the propagation of Christianity in modern Henan Province and its reason through the investigation taking local chronicles as centre [4]. Wang Xinhong had a field trip, and on the foundation of relevant academic research, he analyzed the present situation of Christianity in countryside of Henan Province [5]. Pan Wei, taking Henan as an example, inquired how to play the positive function of rural Christianity in order to serve for constructing a harmonious society [6]. Xia Xin found that there were some deviations in understanding the party's religious policy by rural residents, and accordingly put forward the corresponding suggestions [7].

The existing studies on rural religion have analyzed the characteristics and functions of rural religion, its relationship with new countryside construction, and problems and corresponding reasons and solutions. However, majority of such researches focus on individual level, social dimension or historical geographical environment, minority are from the view of religion itself and discuss the expansion 
of religion. Accordingly, this paper plans to take the method of anthropological fieldwork, and dissects the development state, expansion causes and social functions of Christian faith in $\mathrm{Z}$ village in South Henan through non-structured interviews and participatory observation, which in order to provide reasonable reference for effective strategies adapted to rural society and new socialist countryside construction.

\section{Data and Methods}

Christianity has the history of more than 130 years in Henan, which was introduced into Henan in 1883. Since the reform and opening up, Chinese religious policy has been implemented and international culture exchanges have deepened constantly, especially after the Cold War, the role of religion in the cultural conflict and fusion tends to be increasingly prominent. Those have a hug influence on individuals' understanding of religion and promote Christianity to develop quickly [8]. Against this background, the number of Christians in Henan has ranked first in China, in particular, rural areas developed with a more rapid speed. According to the statistics provided by the Bureau of Religious Affairs, Christians in Henan reached 2.1475million in 2004, and distributed in 157 counties (city, district), 91 percent of towns, 74 percent of sub-district office and 72 percent of villages and 55 percent of neighborhood committee, for which rural Christians accounted 70 percent. Christianity has become an important factor affecting the social structure of Henan. To pay close attention to the development of rural Christianity, and to have guidance on it, would have a great significance for a harmonious society construction.

Taking the advantage of school holidays, our team carried out several times of in-depth investigations in $\mathrm{Z}$ village in Henan Province, and interviewed nearly one hundred Christians. $Z$ village, located in Pingdingshan City, is a natural village that gives priority to with crop production. The reason why did we choose $\mathrm{Z}$ village, the hometown of our team members, is that in the present China, it is difficult to conduct the survey on Christianity, especially for a stranger, since few Christian will accept and cooperate with you. In order to avoid the difficulty, we returned to our hometown to survey.

This study will take the methods of field investigation and documentation. Through in-depth interviews and participatory observation with local respondents, we have a preliminary understanding about the residents' religion as well as the development of Christianity in $\mathrm{Z}$ village.

\section{Development of Christianity in Z Village}

$\mathrm{Z}$ village has more than eighty households, about 400 people in total, and nearly one hundred Christians. If taking the household as unit, almost two-thirds of households have Christians. Besides, Christians in this village are in each age level. So it is quite obvious that Christianity has a trend to expand. The results of basic survey data are shown as follows.

\section{The Traditional Phenomena with a Tendency to be Replaced}

Christian faith in $\mathrm{Z}$ village has a traditional common phenomenon; this is, among Christians, the female, the elderly and the low-education are in the majority. But this phenomenon seems to be changed. The proportion of the male, the young and middle-aged and the high-education are gradually rising. In this investigation, for instance, all respondents are in a gender ratio that male accounts for 33.3 percent and female 66.7 percent. The age structure of the respondents is that above 55 years old 
accounts for 33.3 percent, 35 to 55 years old accounts for 38.1percent, and others are who fewer than 35 years old. From the view of composition of education degree, 47.6 percent of the respondents only have primary education degree or even lower, 23.8 percent of the respondents have junior education degree, and 19.1 percent senior education degree, and 9.5 percent have the university education degree.

\section{Rise of "internal propagation" Promoting Christians to be Younger}

The age of Christians tends to be polarized. Christians fewer than 6 years old and above 30 years old are in the majority, respectively accounts for 28.6 percent and 33.3 percent. People above 30 years old, would prone to seek dependency due to the pressure derived from life and work. But why do Christians fewer than 6 years old account for quite proportion? The statistical results make it clear. Of those people, 57.2 percent contact with religion by their family members or relatives, 33.3 percent by religious acquaintances and only less than 10 percent by clergy. The propagation of Christianity in countryside has been gradually evolved into internal household propagation from external household propagation in 1980s. Thus, Christians fewer than 6 years old are influenced by their family and relatives, not their own rational choice.

\section{Mental Deficiency, and Easy to Be a Christian}

Many studies have shown that religious believers are utilitarian. Facts prove that the phenomenon does exist. The investigation finds, among respondents, 38.1 percent to be religious for treatment, hazard cleanup and blessing; 23.8 percent just for family legacy and 33.3 percent for mental deficiency, only less than 5 percent initiative to get religion. What's more, it is generally unconditional or low-entry to be a Christian, as long as a willing to be religious, you will be accepted. Although there is a "baptism" ceremony, someone usually doesn't be importuned.

\section{Reasons of Christian Expansion in Z Village}

Christianity expands rapidly in rural areas, not only for their particular social context, but directly related to the spiritual needs of contemporary Chinese farmers. This paper carry out a brief analysis on reasons of the Christian expansion focused on the perspective of religion itself.

\section{Reform to be localized}

The form of Christianity is increasingly localized, which lay the foundation for Christianity rooting in rural areas. Yang Hongshan deemed that Christianity had intruded into China four times in history, but almost been driven out each time, since there is a elementary contradiction between the unique requirement of Christianity and superiority and folk belief of Chinese, so that the conflict is inevitable [9]. After 1978, Christianity has been introduced into rural areas with a quite simple ceremony and gradually adapted with rural lifestyle.

Localization of Christianity manifests in many aspects, such as localization of the clergy, adaptation of doctrine to local customs, localization of church site construction and ritual process and even spiritual content, etc. The localization of Christianity is just about the significant cause for promoting farmers to be religious.

Once conflicted with folk customs, Christianity would be still complied with the local form. In daily practice, conflict between Christian behavior and non-Christian behavior, mainly contains ancestor worship, weddings and funerals, and other ceremony such as Chinese New Year and so on. However, Christianity has gradually 
evolved some contents to fuse with local culture, which solve some seemingly irreconcilable conflict to a large extent.

\section{Attraction of Doctrine}

Christianity advocates its doctrine that everyone is equal, each other would be as brothers and sisters, and sufferings in the evil are unable to get rid off and so on. This is easily to be accepted by farmers.

The Christian morality is "patience", the philosophy of "tolerance" and "love", also the secular people theory of "good up". And the Christian commitment is a fantasy, "God will see everything, will punish all and reward all", this leads Christians to forget the trouble from real life. At the same time, the rural Christianity has some unwritten rules on Christian culture and daily behavior, which actually the popularized expression of "self- cultivation" in Chinese traditional culture. More importantly, unlike the doctrine of Buddhism and Taoism is abstruse, Christian doctrine is popularized and easy to be accepted by farmers with low education. They get a temporary mental satisfaction and liberation from Christian doctrine, and then become faithful believers unconsciously.

\section{Innovation of Preaching}

Only in constant innovation, can things last long term and even stand out. Because of innovation and adaption, Christianity gradually roots in China and grassroots. It doesn't limited by original rigid rules, but has the obvious pioneering both on the change of preachers and the openness of religious activities.

First, start using the "new preacher". It is understood that preachers in the past are almost the elders with old ages and be religious. They usually read scriptures, made the preaching boring. But now, the preacher is a middle-aged female Christian, about 40 years old. She preaches to believers with enthusiasm and infection, and usually combines with real life, history and geography and knowledge of scientific inquiry in the process of interpretation. Like this kind of starting using a young energetic preacher, is a very good innovation, which can appeal more people to be religious.

Second, explore new religious activities. According to the information, a proportion of young Christians usually gathers in the village square irregularly, and dances with hand drum or bell to express scriptures, which is similar to current popular "square dance". They expect this fashionable and lively way will appeal more people to join in.

\section{Low entry Threshold}

Compared with other religions, Christianity has a low entry threshold, or even no threshold. As long as a willing to be religious, you will be accepted, but need a "baptism" ceremony. Christianity can adapt to society strongly and easily to satisfy the spiritual demands of Christians, and even carry out religious activities here and there.

\section{Care about Christians without Taking}

Since modern times, rural economy has been depressed, and material life been extreme poverty. Christianity has been used the strong economic foundation of its church to help Christians get through the tough times by giving in charity. Until now, Christian churches often preach through the methods of providing rice, relief, medical care, school and money and so on. Compared with Buddhism and Taoism requiring believers to donate money, the behaviors of Christianity are easy to gain 
unprecedented public approval.

\section{Social Governance Function of Christianity}

The investigation in $\mathrm{Z}$ village finds that Christianity plays a positive function on the rural social governance in its expansion process. Meanwhile, the positive function would promote the construction and development of new socialist countryside. If the party and the government could take a sufficient and appropriate guidance on positive function, Christianity will better serve for new socialist countryside construction.

\section{Moral Indoctrination and Self-discipline}

Christian commandments involve social morality, family morality and individual morality, etc. Those all contain beneficial factors for stabilizing social order and family. Christianity would constraints Christians, regulates their behaviors and guides their thoughts by a large number of commandments, that is to say, Christianity plays the function of moral indoctrination by a form of religion. For instance, there are some people greedy of little rich profits in rural areas, which easily lead to enmity and distrust between each other. While the doctrine of Christianity would produce a constraint force on it, believers usually to be self-disciplined for fear of the god "knowing everything and at everywhere", namely "inner concentration". As a result, Christianity has a great promoting effect on upgrading public morality.

\section{Abolish Outmoded Conventions and Customs to Purify Atmosphere}

The gambling activities, like playing mahjong and taking the deposit, prevail in rural areas; weddings or funerals are required to be high-profile; feudal and superstition activities are in vogue. Those outmoded conventions and customs in rural areas must be repelled to construct rural spiritual civilization and purify social atmosphere. However, Christianity encourages frugality, opposes extravagance and waste on weddings and funerals and takes gambling as the temptation of devil, so it requires believers to away from these bad habits. In addition, the propagation of Christianity promotes the traditional concept of filial piety. Christians in rural areas are generally filial to their parents, which set a good example not only for their children but also for other people, meanwhile promote the harmony of rural households.

\section{Cultural Propagation and Teaching of Literacy}

Christianity has a certain function of cultural propagation in the countryside. The survey finds, after be religious, rural residents gradually become literate and open their minds through religious activities such as learning to sing hymns, reciting the bible or preaching. Many of the aged and people with little literacy accept characters re-education in order to be able to read and understand the bible. Then they can recognize and write simple characters step by step, which manifest their own quality increased. Besides, many clergies preach with some current political news and topics to enrich the spiritual cognition of farmers. All of those would be beneficial to promote the cultural construction of new countryside.

\section{Promote Social Communication and Improve Interpersonal Relationships}

The function of Christianity on social communication could be embodied in strengthening connections among Christians, and encourage Christians to trust and help each other. The doctrine of Christianity regards loving others as loving god, requires Christians to observe their behaviors, speeches and thoughts in the presence of the god. This objectively lays the foundation for improving interpersonal 
relationships. The Christianity also asks Christians to treat marriage and family seriously, which further the domestic peace, and would be beneficial for social stability and harmony of interpersonal relationships.

\section{Results and Discussion}

Since the reform and opening up, Christianity in China has developed with a rapid speed, meanwhile appeals attention of increasing scholars. However, from the view of current domestic Christian studies, major studies are on humanistic thought, minor on empirical study. According to the investigation in $\mathrm{Z}$ village in south Henan Province, this paper analyzed the expansion reasons and social functions of rural Christianity. Conclusions are summarized as follows. Firstly, Christianity expands rapidly in rural areas due to its own religious characteristics. Secondly, in the process of Christian expansion, there are increasing young people to be religious. That changes the group characteristics of rural Christians. Finally, Christianity plays a certain positive function on rural society governance, also becomes an indispensable culture beneficial for maintaining the order of rural life. So how to make better use of the positive functions of rural Christianity and make contribution for new socialist countryside construction? How to further regulate existing rural Christian organizations but does not intervene Christian liberty of belief? Does the change of Christian propagation mode from external household to internal household, reflect changes of social life structure in rural areas at the present stage? The series of issues still need to be explored.

\section{References}

[1] Zhang Yan. Investigation and analysis on religious problems in rural ethic areas. Journal of Southwest Nationalities Collage (Social Science), 1986, (04):55-59.

[2] Wang Jian. Investigation of rural religious faith in N village. Religious Studies, 1989, (Z2):63-66.

[3] OuYang Sutong. Chinese rural religion under the background of transformation. Beijing: Social Science Press, 2009: 8.

[4] Ma Xiaojun. The propagation of Christianity in modern Henan Province-investigation taking local chronicles as centre. Journal of Shangqiu Normal University, 2012, (04): 55-59.

[5] Wang Xinhong. Present situation of Christianity in countryside of Henan Province. Journal of Chongqiong Science and Technology University (Social Science), 2011, (02): 75-77.

[6] Pan Wei. Playing positive function of rural Christianity to serve for constructing a harmonious society-A case of Henan Province. Journal of Sichuan Socialism Institute, 2011, (03): 45-46.

[7] Xia Xin. Investigation and analysis on religious faith of rural residents in Henan Province. Journal of Zhoukou Normal University, 2014, (03): 38-41.

[8] Zhou Yiru. Causes and impacts of Christianity on rural development - A case of Christian situation of M Village. Journal of Chifeng University (Chinese language Philosophy and Social Sciences), 2014, (05): 78-80. 
[9] Yang Hongshan. Survey and reflection of "Christian fever" in countryside in eastern Anhui Province. Jianghuai Tribune, 1994, (04). 